\title{
MỘT SỐ ĐẶC ĐIỂM CỦA QUÁ TRÌNH KHẨN HOANG, XÁC LẬP CHỦ QUYỀN Ở VÙNG ĐẤT NAM BỘ THẾ KỶ XVII-XVIII
}

\author{
Trần Thị Mai ${ }^{i^{*}}$
}

\author{
${ }^{a}$ Trường Đại học Khoa học Xã hội và Nhân văn, Đại học Quốc gia TP. Hồ Chí Minh, \\ TP. Hồ Chí Minh, Việt Nam \\ *Tác giả liên hệ: Email: maitranthi@hcmussh.edu.vn
}

Lịch sử bài báo

Nhận ngày 27 tháng 11 năm 2019

Chỉnh sửa ngày 22 tháng 01 năm 2020 | Chấp nhận đăng ngày 05 tháng 02 năm 2020

\section{Tóm tắt}

Trong hai thế kỷ XVII và XVIII, công cuộc khẩn hoang vùng đất Nam Bộ của chính quyền Đàng Trong và các tầng lớp nhân dân Việt, Hoa, Khmer, Chăm... đã đưa đến việc xác lập chủ quyền trên vùng đất này. Nghiên cúu này trình bày các đặc điểm về quá trình khẩn hoang và xác lập chủ quyền qua các khía cạnh: Quá trình khẩn hoang vùng đất Nam Bộ là sụ tiếp nối quá trình khẩn hoang và mở cõi của các thế hệ nguoòi Việt Nam theo hướng chủ đạo về phuoong nam; Quá trình khẩn hoang vùng đất Nam Bộ là quá trình chinh phục vùng đất hoang nhàn đầy thách thức và khó khăn; Quá trình khẩn hoang vùng đất Nam Bộ là quá trình mở rộng khối đoàn kết cộng đồng theo xu hướng thống nhất và huớng tâm; Quá trình khẩn hoang vùng đất Nam Bộ cũng đồng thời là quá trình xác lập chủ quyền theo phương thức thu đắc lãnh thổ; và Quá trình khẩn hoang và xác lập chủ quyền trên vùng đất Nam Bộ gắn liền với quá trình mở rộng bang giao và nâng cao vị thế quốc gia dân tộc.

Từ khóa: Chủ quyền vùng đất Nam Bộ; Đặc điểm khẩn hoang Nam Bộ; Khẩn hoang Nam Bộ.

DOI: http://dx.doi.org/10.37569/DalatUniversity.10.1.627(2020)

Loại bài báo: Bài báo nghiên cứu gốc có bình duyệt

Bản quyền @ 92020 (Các) Tác giả.

Cấp phép: Bài báo này được cấp phép theo $\mathrm{CC}$ BY-NC 4.0 


\title{
SOME FEATURES OF THE PROCESS OF RECLAIMING AND ESTABLISHING SOVEREIGNTY IN SOUTHERN VIETNAM DURING THE 17TH-18TH CENTURIES
}

\author{
Tran Thi Mai ${ }^{a^{*}}$
}

${ }^{a}$ The University of Social Sciences and Humanities, Vietnam National University Hochiminh City, Hochiminh City, Vietnam

*Corresponding author: Email: maitranthi@hcmussh.edu.vn

\section{Article history}

Received: November $27^{\text {th }}, 2019$

Received in revised form: January $22^{\text {nd }}, 2020 \mid$ Accepted: February $5^{\text {th }}, 2020$

\begin{abstract}
In the $17^{\text {th }}$ and $18^{\text {th }}$ centuries, the reclamation of Southern Vietnam of the Cochinchina government and of the Vietnamese, Chinese, Khmer, Cham peoples, etc. led to the establishment of national sovereignty over this land. This study describes special features of the process of reclaiming and establishing sovereignty through the aspects as follows: The reclamation of Southern Vietnam was the continuation of the expansion process with the key direction towards the South carried out by generations of Vietnamese people; Challenges and difficulties were found in plenty in the conquest of unoccupied lands; The reclamation of Southern Vietnam was the one of expanding the solidified community according to the central tendency and trend of unification; Simultaneously, the reclamation of Southern Vietnam was the one of establishing sovereignty by mode of acquisition of territory; and the reclamation of, the sovereignty establishment over Southern Vietnam was strongly attached to the process of expanding diplomatic relations and raising the status of the nation.
\end{abstract}

Keywords: Features of reclaiming Southern Vietnam; Reclaiming Southern Vietnam; Sovereignty over Southern Vietnam.

DOI: http://dx.doi.org/10.37569/DalatUniversity.10.1.627(2020)

Article type: (peer-reviewed) Full-length research article

Copyright (C) 2020 The author(s).

Licensing: This article is licensed under a CC BY-NC 4.0 


\section{MỞ ĐẦU}

Công việc nghiên cứu, biên soạn lịch sử vùng đất Nam Bộ Việt Nam đã được giới nghiên cứu triển khai từ cuối thập niên 50 của thế kỷ XX. Trong vài chục năm trở lại đây, việc nghiên cứu vùng đất Nam Bộ đã được thực hiện một cách toàn diện và đặt trong sự vận động và phát triển của tiến trình lịch sử dân tộc đã thu hút nhiều sự quan tâm của giới nghiên cứu nói chung và giới sử học nói riêng.

Nhiều cuộc hội thảo khoa học đã được tổ chức và những công trình khoa học nghiên cứu sâu về Nam Bộ đã được công bố, tiêu biểu có thể kể đến: Tập II trong bộ Lịch sư Việt Nam (4 tập) của Trường Đại học Khoa học Xã hội và Nhân văn, Đại học Quốc gia Hà Nội; Cuốn Lược sư vùng đất Nam Bộ của Vũ (2006); Cuốn Lịch sủ hình thành và phát triển vùng đất Nam Bộ tù khởi thủy đến năm 1945 của Trần (2017); Bộ sách Vùng đất Nam Bộ (12 tập) của Phan (2016), bộ sách này được biên soạn trên cơ sở Đề án Khoa học xã hội cấp nhà nước về quá trình hình thành và phát triển vùng đất Nam Bộ; Cuốn Hỏi đáp về lịch sử vùng đất Nam Bộ Việt Nam của Nguyễn (2019)... Kết quả nghiên cứu đã xác lập nhận thức về lịch sử Nam Bộ nói riêng trên các mặt: Diện mạo tự nhiên, dân cư, lịch sử, và văn hóa. Đồng thời nhận thức về Nam Bộ trong tiến trình lịch sử Việt Nam nói chung trên các phương diện: Lịch sử khẩn hoang, sự biến đổi hành chính-dân cư, kinh tế và sự phát triển các đô thị, xác lập và bảo vệ chủ quyền, và vai trò và vị thế của Nam Bộ trong tiến trình lịch sử dân tộc.

\section{MỘT SỐ ĐẶC ĐIỀM CỦA QUÁ TRÌNH KHẨN HOANG VÀ XÁC LẬP CHỦ QUYŶ̀N TRẾN VÙNG ĐÂTT NAM BỘ}

\subsection{Quá trình khẩn hoang và mở cõi của các thế hệ người Việt theo hướng chủ đạo về phương nam}

Có một thực tế là từ thế kỷ thứ $X$, cùng với sự ra đời và lớn mạnh của các triều đại phong kiến Đại Việt, quá trình mở đất về phía nam của nước Đại Việt cũng được đẩy mạnh (Đ. Nguyễn, 1970, tr. 25-43). Quá trình này được thực hiện xuất phát từ nhiều nhân tố gặp gỡ và tích hợp: Sự khẳng định vị thế độc lập của Đại Việt với Trung Quốc; Sự ổn định và phát triển về mọi mặt của Đại Việt; Vị thế của Đại Việt với các nước phong kiến láng giềng phía tây và phía nam ngày càng nâng cao đã đưa đến sự thần phục của họ với Đại Việt; Quá trình suy yếu và nội chiến kéo dài của các vương triều phong kiến láng giềng Champa và Chân Lạp; Quy luật khắc nghiệt của thời đại phong kiến "mạnh được, yếu thua" và "nước nhỏ dựa vào nước lớn". Đến cuối thời Lê Sơ, năm 1471 vua Lê Thánh Tông đã đánh vào vùng đất của vương quốc Chiêm Thành và sáp nhập vùng đất phía bắc đèo Cù Mông vào lộ Thăng Hoa, đổi thành đạo Thừa tuyên Quảng Nam-lãnh thổ của Đại Việt được mở rộng. Với vùng đất của Hoa Anh (Phú Yên và Khánh Hòa ngày nay), Chiêm Thành (Ninh Thuận và Bình Thuận ngày nay), và tiểu quốc Nam Bàn thì Đại Việt đặt lệ thuộc và giám sát chặt chẽ. Lực lượng khẩn hoang giai đoạn nhà Lý ở khu vực Quảng Bình và Quảng Trị chủ yếu là người Việt và một bộ phận lớn người Chăm thì chuyển cư vào địa phận vương quốc Chiêm Thành. Đến thời nhà Trần, với mối quan hệ hôn nhân nên vùng Thuận Hóa được sáp nhập vào Đại Việt và có sự cộng cư của người Việt và người Chiêm Thành. Từ thời nhà Hồ đến thời nhà Lê Sơ, đã xác lập chủ quyền đến vùng đất phía bắc đèo Cù Mông nên thành phần người Việt chiếm đa số (Viện Sử học, 1994). 
Công cuộc mở đất về phía nam tiếp tục được thực hiện trong các thế kỷ XVI và XVII kể từ khi chúa Nguyễn Hoàng vào trấn thủ Thuận Hóa và từng bước xây dựng cơ nghiệp lâu dài cho dòng họ Nguyễn trên đất Đàng Trong (Phan \& Đỗ, 2014, tr. 15-275). Buổi đầu, họ Nguyễn đã chiêu mộ một bộ phận dân cư từ vùng Thanh-Nghệ trở vào, đồng thời chiêu dụ các thành phần dân cư Chăm và các tộc người thiểu số tại chỗ với mục đích khẩn hoang và xây dựng cát cứ nhằm đối phó với họ Trịnh ở Đàng Ngoài. Sau bảy lần chiến tranh Trịnh-Nguyễn thì công việc mở rộng lãnh thổ vào phía nam ngày được đẩy mạnh.

Việc mộ dân khẩn hoang và lập ấp của họ Nguyễn có thuận lợi lớn như: Vùng đất Thuận Quảng trở vào, quỹ đất hoang còn nhiều, dân cư lại thưa thớt, và các chính quyền sở tại suy yếu không mấy quan tâm đến chiến lược phát triển kinh tế. Trong khi đó, ở Đàng Ngoài, sự phá sản của chế độ quân điền, gánh nặng thuế khóa, chiến tranh, và nhất là áp lực gia tăng dân số đã làm xuất hiện tình trạng di cư hàng loạt của nông dân nghèo đến khu vực phía tây giáp biên giới Lào và nhất là phía nam nơi chính quyền Champa đang ngày càng lùi dần về vùng cực Nam Trung Bộ. Càng về sau, bên cạnh công cuộc khẩn hoang do họ Nguyễn tổ chức thì đã xuất hiện ngày càng nhiều hình thức khẩn hoang tự phát của các nhóm nông dân nghèo người Việt không chịu bất kỳ sự ràng buộc nào của các chính quyền đương thời và làm xuất hiện hiện tượng "dân đi trước, nhà nước đi sau". Những nhóm dân xiêu tán mạo hiểm tìm đển vùng đất phía Nam vì họ không thể tiếp tục bám trụ vào quê hương bản quán khi mảnh ruộng khẩu phần đã rơi vào tay địa chủ, không kế sinh nhai, không nơi bám víu, chiến tranh, đói nghèo, gánh nặng tô thuế, và lao dịch đè nặng. Vùng đất phía Nam là vùng đất có chủ, song hậu quả của chiến tranh phong kiến và sự tranh giành quyền lực trong nội bộ các vương triều phong kiến đã khiến đất đai hoang hóa và gần như vô chủ. Lưu dân Việt tìm đến khai khẩn đất hoang và hòa hợp cùng những thành phần cư dân tại chỗ với mục đích duy nhất là có ruộng đất để cày cấy và sinh tồn.

Trong hai thế kỷ XVII và XVIII, công cuộc khẩn hoang và mở cõi về phương nam diễn ra với quy mô và tốc độ nhanh (Hình 1 ). Chỉ mất khoảng một thế kỷ rưỡi (từ đầu thế kỷ XVII đến năm 1757), chính quyền Đàng Trong đã làm chủ hoàn toàn dải đất kéo dài từ cực Nam Trung Bộ đến Nam Bộ Việt Nam ngày nay. Kiến tạo nên thành tựu kỳ vĩ này là công sức và vai trò của các chúa Nguyễn và đặc biệt là của các tầng lớp nhân dân, nòng cốt là cộng đồng cư dân Việt (Trần, 2008).

Bối cảnh chính trị đầy biến động phức tạp của khu vực Đông Nam Á với sự xuất hiện các trung tâm quyền lực mới Xiêm, Myanmar, và Đại Việt (Đàng Trong). Sự khủng hoảng nghiêm trọng đã dẫn đến suy giảm và thậm chí mất quyền kiểm soát đối với đất đai của thần dân và vương quyền của các vương triều phong kiến Champa và Chân Lạp; Luồng thương mại biển Đông cũng trở nên sôi động do sự xuất hiện thế lực mới là thực dân phương Tây; Làn sóng di dân từ Trung Quốc ồ ạt xuống Đông Nam Á do biến động chính trị lớn từ sự thay thế triều đại... là những nhân tố tác động trực tiếp và đẩy nhanh tiến trình Đàng Trong khai phá và xác lập chủ quyền trên đất Nam Bộ. Khéo léo kết hợp giữa các biện pháp chính trị, quân sự, ngoại giao, và kinh tế để can thiệp sâu vào nội bộ chính quyền vương quốc Chân Lạp, đồng thời, tận dụng tốt thành quả khai khẩn đã tự phát diễn ra của các cộng đồng di dân Việt, Hoa, Khmer, Chăm... trên vùng đất Nam Bộ 
nên chính quyền Đàng Trong đã xác lập được chủ quyền của mình trên đất Nam Bộ như ngày nay (Hình 1$)$.

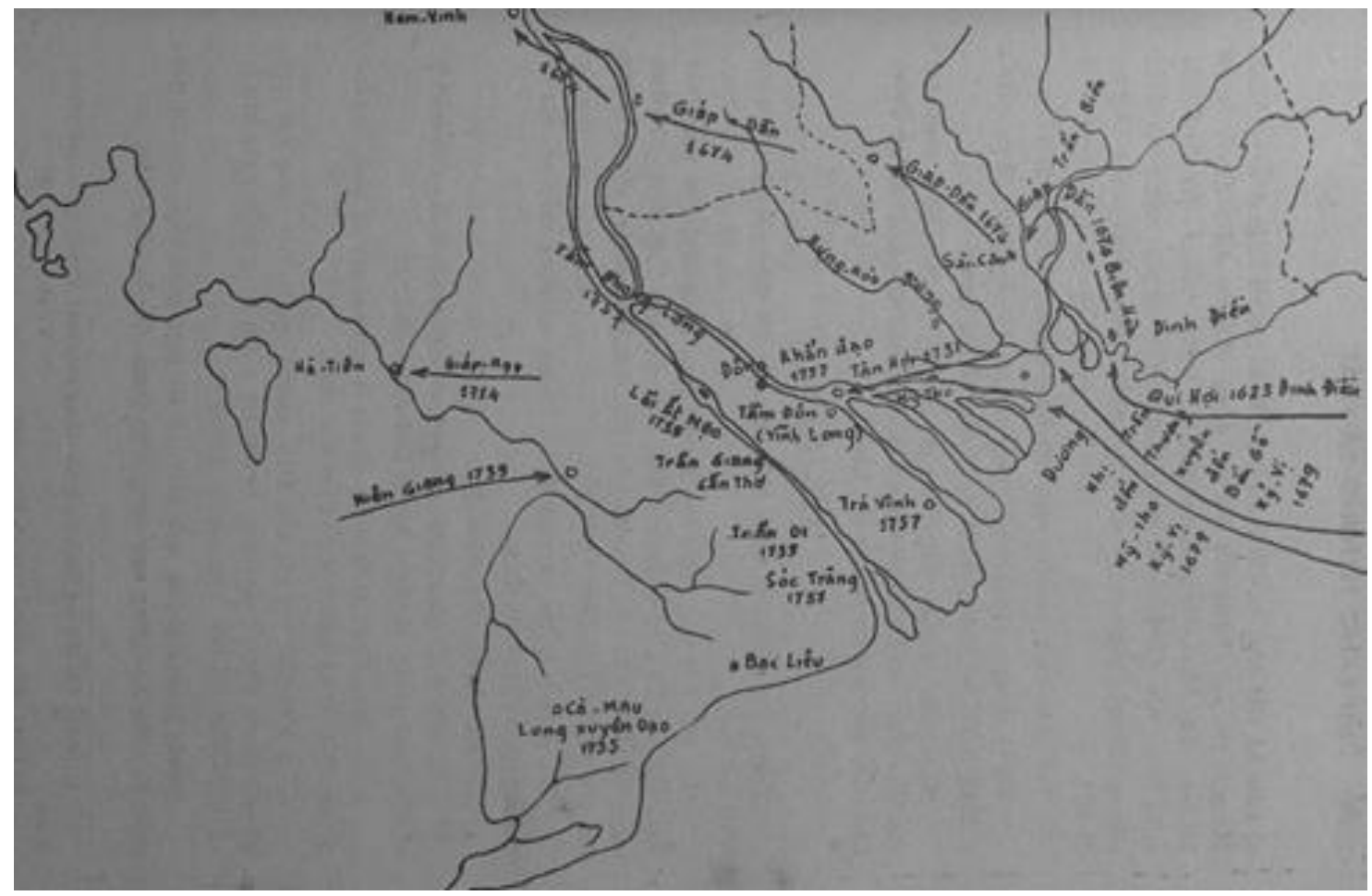

Hình 1. Cuộc Nam tiến xuống đồng bằng Nam Bộ

Nguồn: Phù (1970, tr. 133).

\subsection{Chinh phục vùng đất hoang nhàn đầy thách thức và khó khăn}

Sử liệu ghi chép của Châu (2007), Lê (1961), hay các giáo sĩ phương Tây đã cho biết về một vùng đất Nam Bộ trước thế kỷ XVII với diện mạo "hoang vu", "toàn là rừng rậm", "chỉ thấy ngút ngàn mây cổ thụ và trâu rừng tụ họp"... Tình trạng hoang vu của vùng đất Nam Bộ (Thủy Chân Lạp xưa) là do chính quyền Chân Lạp sau khi đánh bại và làm chủ vùng lãnh thổ của Phù Nam nhưng không thể kiểm soát và khai thác vùng đất đã chiếm được. Nguyên nhân của sự bất lực này là sự kết hợp từ nhiều yếu tố khách quan và chủ quan: Cuộc chiến kéo dài gần một thế kỷ với quân đội Java trên vùng đất Thủy Chân Lạp; Chân Lạp chỉ có thể chiểm đất mà không thể giữ đất do dân số ít; và Tập quán cư trú và sản xuất của dân Chân Lạp là ở vùng thềm cổ sông Sêmun, sông Tonle Sap, và cao nguyên Khorat nên không thể thích nghi với vùng ngập trũng và ven biển.

Tuy vậy, với điều kiện rừng rậm um tùm, đất sình lầy, ngập mặn, nhiễm phèn, thú dữ trên bờ, dưới sông rạch... lại không ngăn được quyết tâm của những lớp cư dân Việt tìm đến Nam Bộ để sinh tồn. Bằng kinh nghiệm chinh phục đầm lầy tích lũy hàng mấy nghìn năm trên vùng châu thổ sông Hồng và sông Mã, lưu dân Việt lần tìm đến những cửa sông và nơi có nước, chặt cây, phát cỏ, khơi kênh rạch, và dẫn thủy nhập điền. Từng nhóm dựa vào nhau khẩn hoang theo lối "móc lõm" và "quảng canh" và dần chinh phục 
được vùng đất “...xưu sở lạ lùng/ Con chim kêu phải sợ, con cá vùng phải kinh”. Bên cạnh đó, những tranh chấp quyền lực giữa các thế lực phong kiến thường xuyên diễn ra và nạn cướp biển hoành hành dọc theo ven biển là những trở ngại rất lớn đối với những lớp lưu dân mạo hiểm tìm đất sống. Nhưng bằng sự cần cù, nhẫn nại, tình nghĩa cộng đồng, và cộng thêm chút "liều lĩnh" đã giúp cư dân Việt trụ được trên mảnh đất màu mỡ nhưng đầy rẫy hiểm nguy rình rập để tạo dựng nên những thôn ấp và ruộng vườn. Đến cuối thế kỷ XVII, đã có vài trăm ngàn người tìm đến khai phá đất hoang trên đất Nam Bộ như kết quả kinh dinh của Nguyễn Hữu Cảnh báo về triều đình Đàng Trong "đất đai mở hơn nghìn dặm và dân số hơn bốn vạn hộ” (Quốc sử quán triều Nguyễn, 2002).

Diện mạo hoang vu của vùng đất Nam Bộ thay đổi nhanh chóng kể từ khi chính quyền Đàng Trong xác lập đơn vị hành chính ở phủ Gia Định năm 1698 và triển khai hàng loạt các biện pháp tích cực nhằm khẩn hoang hiệu quả vùng đất mới: Đào, vét kênh rạch, mở đường giao thông, chiêu mộ các thành phần dân cư (dân nghèo và dân có vật lực), và sử dụng quân đội đồn trú vào khẩn hoang và lập làng. Hình thức đồn điền thì sử dụng lực lượng quân đội, đồn điền dân sự, hay doanh điền được chính quyền chúa Nguyễn và các vua đầu của triều Nguyễn áp dụng phổ biến và tích cực trong khẩn hoang vùng đất Nam Bộ. Nguồn nhân lực đông và có tổ chức là nhân tố có tính quyết định đưa đến thành công của công cuộc khẩn hoang đồng bằng Nam Bộ.

\subsection{Mở rộng khối đoàn kết cộng đồng theo xu hướng thống nhất và hướng tâm}

Tham gia vào quá trình khai khẩn vùng đất Nam Bộ trong các thế kỷ XVII và XVIII gồm nhiều thành phần và lực lượng khác nhau: Các cộng đồng cư dân Việt, Hoa, Khmer, Chăm, Mạ, Stiêng...; Dân nghèo, binh lính, địa chủ... Dù là tự phát họp nhau đi khẩn hoang và lập làng hay được chính quyền tổ chức và hỗ trợ khai phá thì ý thức cộng đồng và truyền thống đoàn kết tương trợ vẫn được xem là điều kiện tiên quyết để thành công trong chinh phục vùng đất mới.

Các cộng đồng cư dân Việt, Hoa, Khmer, Chăm... tuy khác nhau về nguồn gốc tộc người và có mặt trên vùng đất Nam Bộ sớm hay muộn khác nhau, nhưng họ có chung đặc điểm là đều có gốc nông dân và bị phá sản bởi nhiều nguyên nhân khác nhau, trong đó có nguyên nhân chung giống nhau là đều trốn chạy khỏi sự áp bức phong kiến đè nặng. Đặc tính mở về tự nhiên và xã hội của vùng đất Nam Bộ quy định lối quần tụ dân cư mở và các cộng đồng dân cư không cư trú biệt lập theo từng không gian văn hóa tộc người riêng rẽ, mà sống xen cài cùng nhau trong một đơn vị hành chính. Đó chính là thực tế mà Trịnh $(1998$, tr.143) đã quan sát thấy và mô tả "người Kinh và người Thượng tụ tập kết thành chòm xóm" và "Gia Định là đất phương nam của nước Việt, khi mới khai thác, lưu dân nước ta cùng người kiều ngụ như người Đường, người Cao Miên, người Tây Dương, người Phú Lang Sa, người Hồng Mao, người Ma Cao, người Đồ Bà cùng ở lẫn lộn, chung sống thuận hòa, nhưng về y phục, khí cụ thì người nước nào theo phong tục nước ấy”. Hệ quả của quá trình chung sống xen cài lâu dài là sự giao lưu và hỗn dung văn hóa giữa các tộc người, làm đậm đặc thêm truyền thống thống nhất trong đa dạng vốn có của văn hóa Việt. Sống trong mô thức làng "mở”, làng phân bố trải dài theo kênh rạch, nhưng tính cộng đồng luôn được đề cao và yếu tố hàng xóm vẫn được xếp hàng thứ hai trong thang 
bậc ưu tiên khi chọn nơi cư trú "nhất cận thị, nhị cận lân, tam cận giang, tứ cận lộ, ngũ cận điền" (Trần, 2008).

Trong khối cố kết cộng đồng ấy, nổi lên vai trò trụ cột của cộng đồng người Việt với tư cách là cộng đồng có số lượng đông nhất, là lực lượng chủ lực trong khai phá và xác lập chủ quyền, và là chủ thể chính trong giao lưu tiếp biến văn hóa giữa các tộc người, cũng như trong xác lập và bảo vệ chủ quyền trên vùng đất mới. Kể từ năm 1698 , khi chúa Nguyễn Phúc Chu xác lập chính quyền trên đất Nam Bộ, ý thức cộng đồng và ý thức dân tộc càng được cộng đồng Việt phát huy trong công cuộc mở cõi cũng như công cuộc đấu tranh bảo vệ chủ quyền. Tính thống nhất và hướng tâm đã định hình cùng sự hình thành và phát triển của quốc gia Đại Việt tiếp tục khẳng định bền vững trên vùng đất mới.

\subsection{Xác lập chủ quyền theo phương thức thụ đắc lãnh thổ}

Như trên đã đề cập, người Việt mở đất về phương nam không nhằm mục tiêu thống trị hay đồng hóa các dân tộc tại chố, mà là để có đất cày cấy làm kế sinh nhai. Công cuộc mở cõi được tiến hành chủ yếu bởi những cộng đồng cư dân Việt và Hoa qua hoạt động khẩn hoang, lập làng, phát triển kinh tế, nông nghiệp, thủ công nghiệp, và thương nghiệp để mưu cầu sự sinh tồn.

Chính quyền Chân Lạp đã từng quản lý lãnh thổ cũ của Phù Nam trong khoảng gần 10 thế kỷ (từ thế kỷ VII đến thế kỷ XVII). Tuy nhiên, trên thực tế do nhiều lý do đã nêu ở trên, Chân Lạp đã không đủ khả năng kiểm soát, quản lý, và khai thác vùng lãnh thổ chiếm được. Diện mạo hoang vu ngự trị của vùng đồng bằng Nam Bộ đã thu hút người Việt tìm đến khẩn hoang từ khoảng cuối thế kỷ XVI. Trong bối cảnh diễn biến phức tạp của khu vực dưới tác động của nhiều nhân tố khách quan và chủ quan đã đề cập ở trên, một bộ phận hoàng tộc Chân Lạp đã tìm đến nương tựa vào lực lượng chúa Nguyễn ở Đàng Trong nên việc tiến vào khai khẩn ruộng hoang của lưu dân thêm thuận lợi. Trong giai đoạn từ đầu thế kỷ XVII đến giữa thế kỷ XVIII, chính quyền Chân Lạp còn thể hiện thái độ đồng thuận và tạo điều kiện cho chúa Nguyễn tiếp quản các vùng lãnh thổ thuộc vùng đất của vương quốc Phù Nam cũ nên công cuộc khẩn hoang Nam Bộ theo đó được đẩy mạnh.

Năm 1620, vua Chay Chetha II cầu hôn công nữ Ngọc Vạn nên quan hệ giữa chính quyền Đàng Trong và Chân Lạp trở nên thân thiện (Russier, 1914). Dưới ảnh hưởng của công nữ Ngọc Vạn, vua Chay Chetha II đồng thuận cho cư dân Việt được đến khẩn hoang và lập làng ở vùng lưu vực sông Đồng Nai. Trịnh (1998, tr.75) đã nhận xét "địa đầu trấn Gia Định là hai xứ Mỗi Xoài (Mô Xoài), Đồng Nai đã có dân lưu tán của nước ta cùng ở lẫn với người Cao Miên, để khai phá ruộng đất". Năm 1623, Ngọc Vạn góp phần quan trọng trong vai trò cầu nối vận động vua Chay Chetha II đồng thuận giúp chúa Nguyễn đặt được hai trạm thu thuế ở đất Sài Gòn là Prei Nokor và Kas Kobey. Năm 1658, bằng ảnh hưởng của mình với triều đình, bà Ngọc Vạn đã dàn xếp được sự bất ổn chính trị trong triều đình Chân Lạp và đưa Ang Sor lên ngôi vua lấy hiệu là Batom Reachea. Sau sự kiện này, quan hệ Đàng Trong-Chân Lạp càng thêm củng cố, Chân Lạp thần phục Đàng Trong (Quốc sử quán triều Nguyễn, 2002, tr.72) và lưu dân Việt càng thuận lợi hơn để tiến vào lập nghiệp trên vùng Đồng Nai-Gia Định, dần tiến xuống khai phá cả những 
vùng ven biển trải dài từ Cần Giờ đến Hà Tiên và các đảo lớn trên vịnh Thái Lan ${ }^{1}$. Mối lương duyên giữa vua Chay Chetha II và bà Ngọc Vạn đã đặt nền tảng vững chắc cho quan hệ mật thiết giữa Đàng Trong và Chân Lạp kéo dài và đưa tới việc các vua Chân Lạp không chỉ xác lập quan hệ thần phục vào chính quyền của các chúa Nguyễn, mà còn lần hồi cắt tặng các chúa Nguyễn những bộ phận đất đai trên vùng Nam Bộ ngày nay để củng cố quan hệ đồng minh và đồng thời chống lại sự tấn công của Vương quốc Ayudtaya từ phía tây.

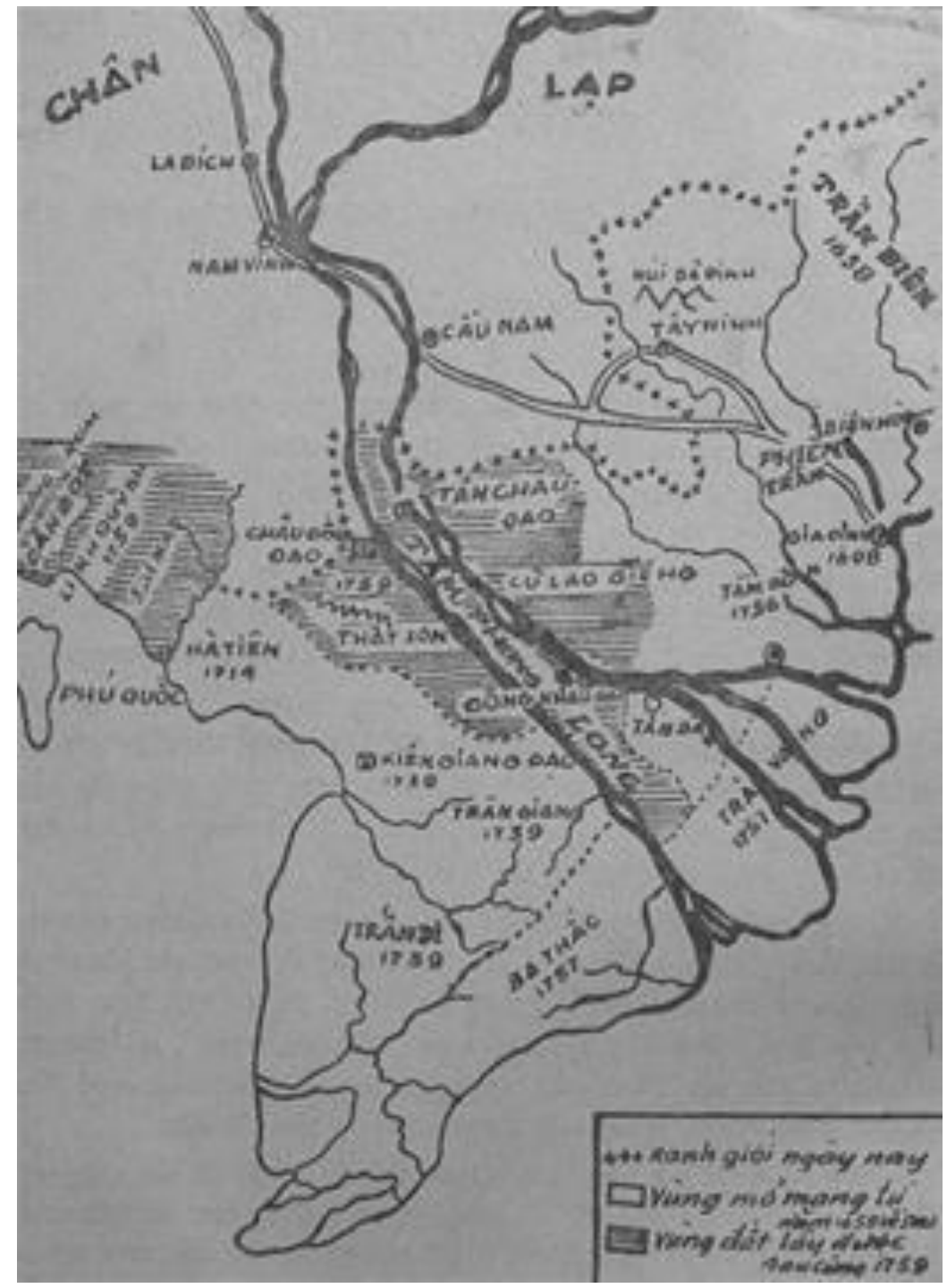

Hình 2. Vùng đất được các chúa Nguyễn xác lập ở Nam Bộ

Nguồn: V. Nguyễn (1970, tr. 4).

${ }^{1}$ Trịnh Hoài Đức, Gia Định thành thông chí (1998), trang 75 “...người Cao Mên sợ phục uy đức của triều đình, lại nhường mà tránh, không dám tranh giành ngăn trở." 
Năm 1674, chúa Nguyễn giúp Chân Lạp dẹp thế lực phản loạn của Nặc Ông Đài và đưa Nặc Ông Thu lên làm Chính vương đóng ở Oudong và Nặc Ông Nộn làm Phó vương đóng ở Sài Gòn (TP. Hồ Chí Minh ngày nay) (Quốc sử quán triều Nguyễn, 2002, tr. 89). Ngoài ra, chúa Nguyễn lại giúp lập đồn dinh ở Tân Mỹ (Sài Gòn-TP. Hồ Chí Minh ngày nay) có giám quân, cai bộ, ký lục, và trại lính để sai phái và bảo vệ. Đồn dinh cũng có nhiệm vụ lập làng, chia xóm, tổ chức phố chợ, và tạo điều kiện cho dân Việt làm ăn sinh sống. Thông qua sự đồng thuận của chính quyền Chân Lạp, năm 1679, nhóm di thần binh sĩ nhà Minh do Dương Ngạn Địch và Trần Thượng Xuyên dẫn đầu đã chạy đến xin chúa Nguyễn che chở đã được tiếp nhận vào khai khẩn đất đai ở xứ Bàn Lân (Biên Hòa) và xứ Mỹ Tho (Tiền Giang) (Trịnh, 1998, tr. 75-76).

Ở miền cực Nam, trên bán đảo Cà Mau, nhóm người Hoa của Mạc Cửu được Chân Lạp cho đất Mang Khảm (sau là Hà Tiên) để lưu trú và khai khẩn. Năm 1708, Mạc Cửu đem đất này tặng cho chúa Nguyễn và xin được làm tôi thần của chúa Nguyễn. Năm 1755, triều đình Chân Lạp xảy ra biến loạn tranh chấp quyền lực, vua Chân Lạp là Nặc Nguyên phải chạy đến Hà Tiên nương nhờ Mạc Thiên Tứ. Mạc Thiên Tứ đã trình tấu và được chúa Nguyễn Phúc Khoát ra tay giúp đỡ đưa Nặc Nguyên trở lại ngai vàng. Năm 1756, Nặc Nguyên xin hiến đất hai phủ Tầm Bôn (Long An) và Lôi Lạp (Gò Công, Tiền Giang) cho chúa Nguyễn. Chúa Nguyễn đã sai Mạc Thiên Tứ tiếp quản đất và cho lệ thuộc vào châu Định Viễn.

Năm 1757, Nặc Tôn trả ơn chúa Nguyễn vì giúp đưa lên ngôi nên đã cắt đất Ba Thắc (Sóc Trăng), Trà Vang (Trà Vinh), và đất Tầm Phong Long (Châu Đốc) tặng chúa Nguyễn (Hình 2). Lại còn cắt riêng năm phủ Hương Úc, Cần Bột, Chân Sum, Sài Mạt, và Linh Quỳnh để tạ ơn Mạc Thiên Tứ đã cưu mang và làm cầu nối với chúa Nguyễn. Mạc Thiên Tứ vâng lệnh chúa Nguyễn tiếp nhận đất và đặt làm hai đạo Kiên Giang và đạo Long Xuyên, sau đó đặt quan lại, chiêu dân cư, và lập thôn ấp.

Như vậy, phần lớn đất đai vùng Nam Bộ đã được các vua Chân Lạp cắt tặng cho chúa Nguyễn với mục đích kiến tạo và củng cố đồng minh để bảo vệ ngai vàng và quyền lực chính trị. Đây chính là hình thức chuyển nhượng tự nguyện của chính quyền Chân Lạp, qua đó giúp các chúa Nguyễn thụ đắc đất đai trên vùng đất Nam Bộ và sáp nhập vào lãnh thổ Đàng Trong.

\subsection{Mở rộng bang giao và nâng cao vị thế quốc gia dân tộc}

Biện pháp ngoại giao luôn được chính quyền các chúa Nguyễn đặc biệt xem trọng trong quá trình đẩy mạnh khẩn hoang và mở cõi về phương nam. Cuộc hôn nhân giữa vua Chay Chetha II và bà Ngọc Vạn là một điển hình của ngoại giao chính trị thời chúa Nguyễn Phúc Nguyên. Sự thành công đem lại từ cuộc hôn nhân này về chính trị là quan hệ đồng minh chiến lược giữa Đàng Trong và Chân Lạp đã thiết lập; Về kinh tế là sự mở rộng vùng khẩn hoang và củng cố thêm cơ sở kinh tế-xã hội cho chúa Nguyễn; Về đối ngoại là chúa Nguyễn không chỉ có thêm đồng minh là Chân Lạp mà còn xác lập được thế cân bằng với vương quốc Ayudtaya của người Thái trong quan hệ khu vực. 
Quá trình đẩy mạnh khẩn hoang vào vùng đất Nam Bộ cũng là quá trình chính quyền Đàng Trong chăm lo phát triển quan hệ láng giềng với các nước trong khu vực Đông Nam Á. Với Chân Lạp, ngoài việc giúp đỡ ổn định triều đình Chân Lạp mỗi khi xảy ra bất ổn, nội loạn và giúp đưa các vị vua Chân Lạp giữ ngai vàng, các chúa Nguyễn còn luôn phối hợp điều động binh mã kịp thời giúp Chân Lạp chống lại những cuộc tấn công của phong kiến Thái vào đất Chân Lạp trong vai trò đồng minh. Mối quan hệ giữa vương quốc Ayudtaya và chính quyền Đàng Trong rất phức tạp vì cả hai đều có tham vọng giành ảnh hưởng đối với các nước nhỏ yếu hơn là Chân Lạp. Tuy nhiên, các chúa Nguyễn vẫn chủ động gây dựng quan hệ ngoại giao chính trị với vương quốc Ayudtaya của người Thái qua trao đổi văn thư ngoại giao, tạo điều kiện cho thương nhân Thái đến Gia Định buôn bán, và nhất là qua vai trò của triều đình Chân Lạp và dòng họ Mạc ở Hà Tiên để hóa giải phần nào những căng thẳng và xung đột quyền lợi giữa vương quốc Ayudtaya và Đàng Trong trên đất Chân Lạp.

Thành quả của công cuộc khẩn hoang và xác lập chủ quyền thời các chúa Nguyễn trên vùng đất Nam Bộ trong hai thế kỷ XVII và XVIII đã mang đến một diện mạo hoàn toàn mới cho vùng đất này: Tình trạng hoang vu lùi xa và thay vào đó là ruộng vườn, làng mạc, và thôn ấp trù phú, phong đăng; Dân cư tụ hội về ngày càng đông đúc; Phố chợ, đô thị, và thương cảng mọc lên, thu hút nhiều thương nhân trong khu vực và ngoài khu vực tụ hội về. Sự thịnh vượng của các thương cảng Cù Lao Phố, Mỹ Tho Đại Phố, Hà Tiên, Sài Gòn-Chợ Lớn... đã thu hút thương nhân Trung Quốc, Nhật Bản, Ấn Độ, các nước Đông Nam Á, và phương Tây đổ về làm ăn. Có thể nói, kinh tế vùng Nam Bộ không chỉ khởi sắc và sớm mang tính chất của một nền kinh tế hàng hóa, mà còn hội nhập tích cực vào luồng thương mại biển Đông trong vai trò nguồn cung hàng hóa, nhất là lúa gạo, cũng như vai trò kết nối các thương cảng trong khu vực lưu vực sông Mêkông và vịnh Thái Lan. Hệ thống thương cảng ở Nam Bộ trong mối quan hệ mở và gắn kết với hệ thống thương cảng của Đàng Trong, với khu vực, và với quốc tế là nhân tố quan trọng góp vào sự thành công trong kiến tạo quan hệ bang giao của các chúa Nguyễn.

Những thành tựu đối ngoại của các chúa Nguyễn vừa là kết quả là động lực của quá trình khẩn hoang và xác lập chủ quyền trên vùng đất Nam Bộ. Mặt khác, đây cũng là quá trình góp phần khẳng định và nâng cao vai trò và vị thế của quốc gia dân tộc trong khu vực và quốc tế.

\section{KẾT LUẬN}

Quá trình khẩn hoang và xác lập chủ quyền của chính quyền Đàng Trong trên vùng đất Nam Bộ ngày nay là kết quả vận động của nhiều yếu tố khách quan và chủ quan mà chính quyền Đàng Trong đã nắm bắt và tận dụng thành công. Thế kỷ XVII và XVIII là thời kỳ hoàn thành công cuộc mở cõi và định cõi của các chúa Nguyễn và các cộng đồng cư dân trên đất Nam Bộ, giúp định hình bản đồ Việt Nam như ngày nay.

Công cuộc khẩn hoang, mở cõi, và định cõi đó vừa phản ánh những đặc điểm mang tính quy luật chung của lịch sử Việt Nam: Xu hướng tiến về phương nam khẩn hoang và lập làng; Xu hướng thống nhất và hướng tâm; Xu hướng thân thiện và hòa hiếu với các quốc gia láng giềng, vừa phản ánh tính đặc thù của lịch sử vùng đất Nam Bộ 
đương thời: Tính mở cả về tự nhiên và xã hội thu hút dân nhập cư tìm đến; Sự khủng hoảng và tự để mất quyền kiểm soát lãnh thổ của các thế lực cầm quyền cũ; Vai trò và vị thế ngày càng gia tăng trong khu vực của thế lực chúa Nguyễn ở Đàng Trong.

\section{TÀI LIỆU THAM KHẢO}

Châu, Đ. Q. (2007). Chân Lạp phong thổ ký (H. Lê, Dịch). TP. Hồ Chí Minh, Việt Nam: NXB. Văn nghệ.

Lê, Q. Đ. (1961). Phủ biên tạp lục. Hà Nội, Việt Nam: NXB. Khoa học Xã hội.

Nguyễn, Đ. T. (1970). Nam tiến Việt Nam. Tập san Sủ Địa, (19-20), 25-43.

Nguyễn, Q. N. (2019). Hỏi đáp về lịch sủ vùng đất Nam Bộ Việt Nam. TP. Hồ Chí Minh, Việt Nam: NXB. Đại học Quốc gia TP. Hồ Chí Minh.

Nguyễn, V. H. (1970). Sự thôn thuộc và khai thác đất Tầm Phong Long-chặng đường cuối cùng của cuộc Nam tiến. Tập san Sử Địa, (19-20), 3-24.

Phan, H. L. (2016). Vùng đất Nam Bộ. Hà Nội, Việt Nam: NXB. Chính trị quốc gia Sự thật.

Phan, H. L., \& Đỗ, B. (2014). Nguyễn Hoàng-Ngườ mở cõi. Hà Nội, Việt Nam: NXB. Chính trị Quốc gia.

Phù, L. T. B. P. (1970). Lịch sử cuộc Nam tiến của dân tộc Việt Nam. Tập san Sủ Địa, (19-20), 45-137.

Quốc sử quán triều Nguyễn (2002). Đại Nam thục lục (Tập 1). Hà Nội, Việt Nam: NXB. Giáo dục.

Russier, H. (1914). Histoire somaire du royaume de Cambodge, des origines à nos Jours. Saigon, Vietnam: Lmprimerie Commerciale C. Ardin-Tous Droits Réservés.

Trần, Đ. C. (2017). Lịch sủ hình thành và phát triển vùng đất Nam Bộ tù khởi thủy đến năm 1945. Hà Nội, Việt Nam: NXB. Khoa học Xã hội.

Trần, T. M. (2008). Vai trò của cộng đồng nguời Việt trong công cuộc khai phá đồng bằng sông Củu Long (thế kỉ XVII-XIX) (Báo cáo tổng hợp Đề tài cấp Bộ). Trường Đại học Khoa học Xã hội và Nhân văn TP. Hồ Chí Minh, Việt Nam.

Trịnh, H. Đ. (1998). Gia Định thành thông chí. Hà Nội, Việt Nam: NXB. Giáo dục.

Viện Sử học (1994). Di dân của người Việt tù̀ thế kỷ X đến giữa thế kỷ XIX. Hà Nội, Việt Nam.

Vũ, M. G. (2006). Lược sủ vùng đất Nam Bộ. Hà Nội, Việt Nam: NXB. Thế giới. 